\title{
Are student jobs flexible jobs? Using online data to study employers' preferences in Slovakia
}

\author{
Lucia Mýtna Kureková ${ }^{*}$ and Zuzana Žilinčíková ${ }^{2}$
}

\author{
* Correspondence: \\ kurekova@governance.sk \\ ${ }^{1}$ Slovak Governance Institute, IZA \\ and CELSI, Štúrova 3, 81102 \\ Bratislava, Slovakia \\ Full list of author information is \\ available at the end of the article
}

\begin{abstract}
This paper analyses patterns of student employment in Slovakia where the numbers of university graduates have risen significantly. We use online job vacancy data and compare 'student jobs' and 'flexible jobs' to understand differences and similarities between the student and flexible labour markets that are often seen as identical. We find substantive differences in the required skill profiles between student-focused vacancies and those based on flexible forms of contract. In addition, student-targeted vacancies can be found across the occupational ladder, which refutes propositions that the student labour market is only precarious, temporary and part-time. From a policy perspective, our findings imply that any regulation of the flexible labour market will only partially address the student labour market.

JEL Classification: J23, J21, J24, J63

Keywords: Youth, Students, Employers, Flexible labour market, Big data, Skills, Slovakia
\end{abstract}

\section{Introduction}

Recent decades have been characterized by a rapid increase of working students (Häkkinen 2006; Moreau and Leathwood 2006; Baffoe-Bonnie and Golden 2007). Several related perspectives regarding the growth of student employment can be identified in the literature (Pollmann-Schult 2005; Eichhorst et al. 2013). The supply perspective suggests that students seek jobs for which they are typically overqualified due to the need to finance their university education (Curtis and Lucas 2001; Moreau and Leathwood 2006; Hall 2010; Beblavý et al. 2013). This is related to the process of the massification of tertiary education, which has made university education accessible to less wealthy individuals and increased competition among students for the most attractive jobs.

The demand perspective views the issue of student work in the context of broader structural changes caused by technological change and the rise of the service sector. This has caused changes in labour demand towards general skills and flexible labour. Jobs that are created in the service sector are seen as unsuitable to traditional lowskilled workers, typically older and male, due to the poor job quality and security, low pay and limited opportunities for advancement. Students are seen as particularly suited to supply flexible labour and the soft skills that work in the service sector requires (Curtis and Lucas 2001; Manning 2004; Maselli 2012). In spite of low hard skill requirements, the tasks performed in low-skilled jobs can be rather complex in terms of

(C) The Author(s). 2016 Open Access This article is distributed under the terms of the Creative Commons Attribution 4.0 International License (http://creativecommons.org/licenses/by/4.0/), which permits unrestricted use, distribution, and reproduction in any medium, provided you give appropriate credit to the original author(s) and the source, provide a link to the Creative Commons license, and indicate if changes were made. 
the 'soft skills' demanded, such as communication skills, trainability, flexibility, social skills and appearance, making student workers able to respond to the skill needs of firms (Autor et al. 2003; Maxwell 2006; Brunello and Schlotter 2011; Beblavý et al. 2016).

A third perspective suggests that the work-study shifts might have been encouraged by changing expectations of the skill set that university graduates should bring to the labour market. Experience ranks high in employers' preferences, and this increases the incentives for young people to seek practical experience while still in education (Quintini and Martin 2014; Beblavý et al. 2016).

Existing academic literature tends to equate the student labour market with the flexible labour market in the low-skilled segment and offers relatively general evidence about the characteristics of the student labour market. Moreover, the student labour market is often matched with youth labour markets (Quintini and Martin 2006; O'Higgins 2012; Eichhorst et al. 2013). However, a large proportion of university students are above the age of 25 (Fabo and Beblavý 2015).

This paper aims to fill some of these gaps and analyses the features of the student labour market from a labour demand perspective. We ask whether the student labour market is identical to the flexible labour market. We compare and contrast the skill requirements for student jobs and for flexible jobs and analyse how employer demand for students has responded to macroeconomic conditions in the crisis and post-crisis periods. We rely on a relatively novel type of data and analyse online job advertisements gathered in Slovakia between 2009 and 2014. Our definition of student jobs is demanddriven and includes those vacancies for which employers marked in the educational requirement field that it is suitable for university or high school students or labelled it as an internship. We define flexible job offers as vacancies that are offered on the basis of flexible types of contracts-temporary or part-time contracts.

Slovakia has suffered from high unemployment rates, whereby youth and the lowskilled are particularly disadvantaged, and since the regime change, the country has experienced a rapid expansion of tertiary education. In 2012, around 56\% of young people aged 20-24 years were enrolled in tertiary education, but only about $5 \%$ of students under 25 years were working in Slovakia compared to 22\% on average in the EU27 (Fabo and Beblavý 2015). Most Slovak universities offer distance learning degrees which allow students to combine (full-time) employment and studies (CVTI SR 2016). Between the years 2009 and 2014, distance learning students formed 24 to 33\% of all registered university students. These students are typically older than full-time students, adding to the overall body of working students in the country. Flexible employment in Slovakia is also relatively rare. In 2014, only $5 \%$ of individuals worked in part-time employment in the total population, although roughly $11 \%$ of employed youth (15 to 24 years) had part-time contracts (Eurostat).

Our key contribution lies in providing a labour market demand perspective on the student job market using online vacancies. Although online data has its limitations, research using this data for studying labour market issues is expanding (Edelman 2012; Askitas and Zimmermann 2015; Kureková et al. 2015). The question we investigate is important also from a policy perspective, as student employment in different forms has been promoted across Europe as a tool to fight youth unemployment. We need to understand more closely whether the student labour market equals the flexible labour market and how it is affected by macroeconomic conditions. 
The rest of the paper is structured as follows. Section 2 reviews the relevant literature. Section 3 explains the methodology and data. Section 4 is the empirical section. We then present a discussion of the results in Section 5, and Section 6 concludes.

\section{Student labour market: what do we know?}

2.1 The quality of student employment: temporary, part-time, informal?

Student employment and the employment of young workers ${ }^{1}$ have several specific features that in most countries tend to systematically differentiate it from the employment of prime-age workers (Quintini and Martin 2006, 2014; Hall 2010). An initial distinguishing feature is the temporary nature of student jobs. More than $40 \%$ of young employees (aged 15-24) in the EU were on temporary contracts in 2011, which was about three times higher than for those aged 15-64 (Eichhorst et al. 2013). The incidence of temporary work among youth has risen during the crisis, becoming a dominant form of new employment contracts for young people in many EU countries (O'Higgins 2012; Eichhorst et al. 2013).

Second, many young workers also work in part-time jobs which typically require fewer skills and yield lower salary and lower job status than full-time jobs (Kalleberg 2000; Hirsch 2005). Flexible or shorter working hours might not be attractive only for students but might also be preferred by people engaged in home production, older workers and women (Pfeffer and Baron 1988; Del Boca 2002). There is great variation within the part-time job offers, and along with the marginalization of the less skilled, this could also be employers' strategy to attract or keep skilled workers who prefer flexible working arrangements (Quintini and Martin 2006). Third, young people are also more likely to work informally, together with the low educated, the elderly and individuals with disabilities (Hazans 2011). This accentuates the precarious environments in which student work might be performed in some sectors.

However, some studies suggest that not all student and graduate employment needs to be in temporary, part-time and precarious jobs. Research into the student and graduate labour market in the UK shows that there are openings for young workers across different sectors, including in highly skilled specialized sectors (Purcell and Elias 2003, 2003; Purcell et al. 2004). The previous findings also point to the need to distinguish student and youth workers. Fabo and Beblavý (2015) reported that even though the majority of EU students are under 25 years old, it is mainly the older group of students $(25+)$ that is more likely to be employed. Moreover, the older student workers often identify themselves as workers rather than students. In sum, the student youth labour market is heterogeneous and there is a need for a clear distinction between young people who are simply in the labour market and those who are combining education and employment (Canny 2002).

\subsection{How working impacts the labour market outcomes for students}

Most existing studies tend to focus on the link between working during studies and educational outcomes. The majority of the studies report a negative effect of term-time work on educational outcomes caused by tiredness, missed classes and deadlines and difficulties in managing work and study commitments in parallel (Ford et al. 1995; Broadbridge and Swanson 2005; Broadbridge and Swanson 2006). Full-time work is 
more harmful to academic performance than part-time work arrangements. On the other hand, Quintini and Manfredi (2009) show that students who work and study at the same time have a greater likelihood of obtaining a favourable labour market outcome after graduation. However, this does not seem to be true for students who work outside their field of study (Quintini and Martin 2014).

More recent research also considers the fact that there could be complementarities, not only substitutability, between paid work and education (Hall 2010). Beerkens et al. (2010) find only a very small negative effect on academic performance and labour market outcomes for students in Estonia. Employment parallel to study sends a signal to employers about the quality of the graduates who enter the labour market. Work experience during studies can support the development of a number of soft skills, including time management, a sense of responsibility, job-search skills or increased confidence (Häkkinen 2006; Baffoe-Bonnie and Golden 2007; Guile and Griffiths 2010).

Finally, higher education wage and employment premiums can be found in various countries (Little and Arthur 2010) despite the generally declining time spent on study (Baffoe-Bonnie and Golden 2007; Babcock and Marks 2011).

\subsection{The student labour market and macroeconomic conditions}

While it is clear that an economic downturn affects the labour market negatively, international literature agrees that this is particularly the case for youth (Scarpetta et al. 2010; Kelly and McGuinness 2015). Beyond the cyclical component of youth unemployment, there are structural reasons. The 'youth experience gap' in terms of generic and job-specific experience is among the key factors explaining higher youth unemployment relative to the general population (Ryan 2001; Caroleo and Pastore 2007; Choudhry et al. 2012). The incidence of temporary employment among youth rose significantly during the Great Recession, and youth employment fell dramatically especially in flexible labour markets (O'Higgins 2012). Choudhry et al. (2012) show that financial crises have a negative effect on youth employment for as long as 5 years, controlling for the effect of GDP growth. While there is a rich body of studies investigating the effect of macroeconomic conditions or institutional factors on youth employment in general, much less is known about the effect of the economic conditions of student employment in particular.

The hypotheses derived from the reviewed literature imply that the student labour market and flexible labour market will be very similar in terms of sector and skills and they will be positioned in the low-skilled labour market segment. Our further expectations are that the recent economic downturn (high unemployment rates and decline in GDP growth) has affected the student labour market negatively.

\section{Methodology and data}

We base our analysis on online vacancy data, which we received from the largest private online job portal based in Slovakia called Profesia.sk (www.profesia.sk). The portal covers $80 \%$ of the Slovak job vacancy market (Štefánik 2012; Beblavý et al. 2016). It is able to collect significantly more job offers than registered vacancies collected by the public authorities (Fig. 1). We work with the population of job advertisements, that is, all advertisements gathered by the portal between 2009 and June $2014^{2}$ (see Fig. 1). 


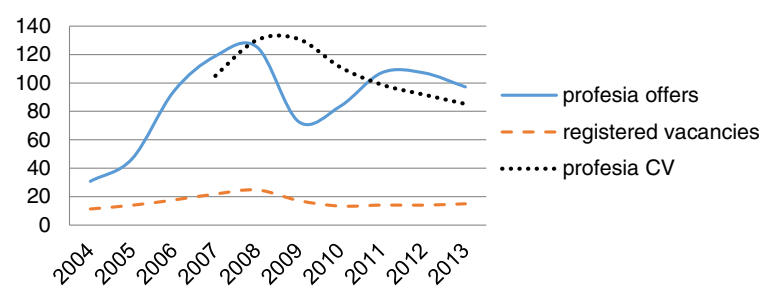

Fig. 1 Job vacancies and CVs posted on Profesia and registered vacancies (in thousands)

The total number of job offers that we received was 512,216, after cleaning the data we were able to work with 493,853 observations (Table 1).

The portal gathers data in a relational database composed of predefined fields. The fields include the required level of education, position name, type of contract, region where the work is advertised, required skills (language, computer or administrative), whether experience is required, and a range of salary (min-max) offered. We identify unique observations on the basis of a unique ID number ascribed automatically to a job vacancy through the portal's database system. Data is organized according to the portal's own classification system that employers are required to use when posting a job offer.

While the size of our data pool is remarkable, online data also have their biases. These partly relate to the profile of Internet users and the character of firms that advertise job vacancies. First, over $42 \%$ of portal visitors are aged less than 30 years, about $30 \%$ of visitors have attained tertiary education and close to a half have secondary education with maturita (school leaving certificate). This implies that a fair proportion of job seekers are likely to be students (AIM Monitor 2014). ${ }^{3}$ Given the focus of this research on the student labour market, we consider these biases an asset rather than liability. Second, about 70\% of the firms posting advertisements between 2009 and 2014 belonged to small- and medium-sized enterprises (based on the number of employees; Profesia data, not displayed). This is important as the service industry, where most student and flexible employment is likely to concentrate, is primarily composed of SMEs (Broadbridge and Swanson 2006).

\subsection{Defining and measuring student jobs and flexible jobs}

We take a twofold approach to identifying our subsamples of interest. In order to identify student vacancies, we use information about the required level of education for an advertised job. ${ }^{4}$ We consider student jobs those vacancies that were marked as being suitable for high school and university students. We also add those vacancies that were clearly marked

Table 1 Share of student jobs in total vacancies

\begin{tabular}{llllllll}
\hline & 2009 & 2010 & 2011 & 2012 & 2013 & 2014 & Total \\
& $\%$ & $\%$ & $\%$ & $\%$ & $\%$ & $\%$ & $\%$ \\
\hline Student jobs & 6.2 & 5.4 & 6.2 & 7.9 & 10.4 & 10.3 & 7.6 \\
Flexible jobs & 9.5 & 11.4 & 12.4 & 14.7 & 15.2 & 15.6 & 13.2 \\
Share of flexible jobs within student jobs & 67.0 & 74.0 & 67.0 & 61.0 & 53.0 & 54.0 & 61.0 \\
Total N & 65,029 & 79,225 & 102,103 & 102,130 & 92,913 & 52,453 & 493,853 \\
\hline
\end{tabular}


as student internships. Our definition of the student labour market is, therefore, demanddriven and data-driven. This does not allow us to distinguish whether those who take the advertised positions are young or older students at the definitional level. In order to identify flexible jobs, we use the information about the type of contract related to a vacancy. In the Slovak legislative context, two main flexible forms of employment in terms of flexible working hours are part-time employment and 'work agreement' (part-time, temporary contract without job security typical for the Slovak labour market). ${ }^{5}$ We consider job vacancies for which employers specified these types of flexible contract as flexible job offers.

The given categorizations have remained unchanged during the observed years, and the job portal did not shift its specialization towards any specific labour market group during that time. Similar to the education field, the types of contract could be marked non-exclusively, meaning that several categories could have been marked by an advertising subject, and in most vacancies, this was also the case.

The share of student and flexible vacancies in the whole population of vacancies is displayed in Table 1 . While the vast majority of job offers are non-student and/or nonflexible, a clear growth trend in both student and flexible job offers is evident over time. The share of student job offers increased from $6.2 \%$ in 2009 to $10.3 \%$ in 2014, and the increase in the share of flexible job offers is proportionally similar-from $9.5 \%$ in 2009 to $15.6 \%$ in 2014 . There are more offers with a flexible work contract than student job offers: about a third of the offers with a flexible contract are also categorized as offers aimed at students. This shows, as suggested by the literature, that the flexible labour market is broader and covers more diverse workers than student workers. On the other hand, offers aimed at students are often (61\%), although not exclusively, offers with a flexible contract. This means that nearly $40 \%$ of offers that employers find suitable for students are full-time. This might be a specificity of the Slovak context, which offers distant university courses that can be pursued alongside work.

\section{Empirical analysis}

Our empirical analysis consists of a general descriptive analysis of all vacancies and a logistic regression where we estimate the characteristics of student jobs and flexible jobs.

\subsection{Descriptive statistics}

The descriptive statistic is to be found in Table 2. In terms of occupational groups, student and flexible offers are over-represented in the auxiliary worker category and under-represented in the managerial categories, relative to non-student offers and traditional offers, respectively. However, a significant share of student and flexible offers are among job offers for medium-skilled positions. In terms of occupation, we do not observe a different pattern for offers aimed at students and flexible contract offers, although generally, more offers aimed at students are among the higher skilled positions.

The sectoral concentration ${ }^{6}$ of student jobs is in line with theoretical expectations. Close to two thirds of student and flexible job offers are related to vacancies in traditional service sectors, but a relatively high share of the flexible and student offers is also to be found in the manufacturing industry.

We present two types of measures for the required level of education: mean minimum and mean maximum education. The mean minimum education figures show that 
Table 2 Distribution of key characteristics in student jobs and in flexible jobs

\begin{tabular}{|c|c|c|c|c|}
\hline & Student jobs & Non-student jobs & Flexible jobs & Traditional jobs \\
\hline Auxiliary worker & 12.4 & 3.6 & 15.5 & 2.5 \\
\hline Qualified labourer & 22.4 & 15.3 & 29.4 & 13.8 \\
\hline Administrative worker & 19 & 11.9 & 15.2 & 12.1 \\
\hline Qualified technical worker & 13.4 & 23.4 & 10.2 & 24.5 \\
\hline Qualified non/technical worker & 23.7 & 27.2 & 22.2 & 27.6 \\
\hline Lower and middle management & 8.8 & 17.1 & 7.2 & 17.8 \\
\hline Top management & 0.3 & 1.7 & 0.3 & 1.8 \\
\hline Agriculture, forestry and fishing & 0.4 & 0.7 & 0.7 & 0.7 \\
\hline Mining, quarrying and manufacturing & 15.6 & 14.1 & 19.1 & 13.5 \\
\hline Construction & 1.8 & 2.8 & 2.5 & 2.7 \\
\hline $\begin{array}{l}\text { Wholesale and retail, transportation and } \\
\text { storage, accommodation and food }\end{array}$ & 29.8 & 24.1 & 32.9 & 23.3 \\
\hline Information and communication & 8.9 & 13.5 & 5.2 & 14.3 \\
\hline Financial and insurance activities & 5.7 & 6.2 & 4.4 & 6.4 \\
\hline $\begin{array}{l}\text { Professional, scientific, technical, administrative } \\
\text { and support service activities }\end{array}$ & 33.5 & 34.9 & 28.8 & 35.7 \\
\hline $\begin{array}{l}\text { Public administration, education, social work } \\
\text { activities }\end{array}$ & 3 & 2.9 & 4.4 & 2.7 \\
\hline Other services & 1.4 & 0.9 & 2 & 0.7 \\
\hline Mean minimum education ${ }^{a}$ & 3.3 & 5 & 3.5 & 5.1 \\
\hline Mean maximum education ${ }^{a}$ & 7.3 & 7.1 & 6.6 & 7.2 \\
\hline Experience & 13.2 & 31.6 & 16.2 & 32.4 \\
\hline No skills & 32.9 & 25.9 & 47.9 & 23.2 \\
\hline Administrative skills & 8.6 & 8.1 & 9 & 8 \\
\hline Computer skills_-user & 36.9 & 35.7 & 30.7 & 36.6 \\
\hline Computer skills_-programmer & 5.8 & 4.3 & 3.2 & 4.7 \\
\hline Computer skills_administrator & 1.1 & 1.8 & 0.6 & 1.9 \\
\hline Language skills & 53.5 & 63.7 & 38.5 & 66.6 \\
\hline Agency offer & 31.9 & 42 & 34.4 & 42.3 \\
\hline Mean minimum salary (euro per month) & 728 & 1050 & 629 & 1103 \\
\hline Bratislavský region & 40.9 & 43.5 & 37.7 & 44.3 \\
\hline Banskobystrický & 5.4 & 4.7 & 6.4 & 4.5 \\
\hline Žilinský & 6.7 & 5.8 & 7.8 & 5.6 \\
\hline Trenčiansky & 5.8 & 5.7 & 6.7 & 5.5 \\
\hline Trnavský & 7.8 & 6.8 & 9.1 & 6.5 \\
\hline Nitriansky & 7.2 & 6.8 & 8.4 & 6.6 \\
\hline Prešovský & 6.1 & 4.4 & 6.6 & 4.2 \\
\hline Košický & 7.2 & 6.8 & 7.6 & 6.7 \\
\hline Slovakia—not specified & 3.0 & 3.1 & 3.0 & 3.1 \\
\hline Abroad & 10.0 & 12.4 & 6.9 & 13.1 \\
\hline
\end{tabular}

${ }^{a}$ Mean minimum and maximum education is not a distributional value, but the mean value from the educational scale: 1-primary, 2-secondary school student, 3-secondary without leaving certificate, 4-secondary with leaving certificate, 5-university student, 6- higher professional education, 7-BA, 8-MA, 9-PhD

${ }^{b}$ Salary was recalculated per month and in euros. We applied cut-off points 10-9999 for minimum salary and 10-50,000 for maximum salary

'Due to the possibility of multiple assignments of positions to occupational groups, sector and skills, the number of observations analysed for occupational group is 709,552 , for sector 654,335 , for skills 688,747 and for regions 580,587 . The calculation of wages is based on $N=58,289$ due to the large number of missing values. For all other categories, $N=493,853$ 
student and flexible jobs are offered to less educated individuals in comparison to non-student and traditional jobs. For the maximum level education identified by employers, this is not the case. For offers aimed at students, but not based on a flexible work contract, the mean maximum education is higher than for offers that are not aimed at students. This suggests that student jobs are not exclusive to a certain educational category but rather are less dependent on the attained education of the prospective applicants. This could also imply that student jobs are unrelated to the field of study or actual skills.

We measure skill requirements by evaluating predefined skill categories-language skills, computer skills and administrative skills. On average, student job offers are less demanding in the desired skill set, and it is even more pronounced for flexible work contract offers. For example, $67 \%$ of traditional offers require knowledge of a language compared to $39 \%$ of flexible offers. The gap diminishes to only $10 \%$ when considering student and non-student offers.

Only about $13 \%$ of positions advertised as suitable for students requested previous experience. Among non-student jobs, the share is more than twice as large. Flexible job offers are slightly more likely to require experience than student offers, but it is still half the number of traditional job offers. Concerning the geographical location of the vacancies, most vacancies are available in and around the capital city, due to the concentration of economic activity in the Bratislava region. Differences between student and non-student job offers or flexible and traditional job offers in terms of spatial distribution do not appear to be significant.

\subsection{Characteristics of student job offers and flexible job offers}

In order to determine the characteristics of student jobs and flexible jobs in a robust way, we estimate a probabilistic regression analysis (logit) with clustered standard errors. ${ }^{7}$ We use two dependent variables and estimate the likelihood of student vacancy and flexible vacancy. The analysis helps us to define the determinants of student offers, better grasp features of the student labour market and contrast this with job offers based on flexible work contracts.

The model includes all available characteristics of job offers (occupational group, sector, minimum and maximum required education, experience, skills, agency offer and minimum salary); macroeconomic variables (GDP growth and unemployment rate) ${ }^{8}$ and year dummies. These were added in order to test the effect of macroeconomic conditions on the growth of student jobs in the crisis and post-crisis periods. We estimate two models for each dependent variable, one with year dummies (M1-M2) and one with the macroeconomic variables (M3-M4). ${ }^{9}$ The results are presented in Table 3.

\section{Discussion of results}

We observe an important variation in the strength of the effect of independent variables and also, albeit more rarely, in the direction of the effect in student offers versus flexible offers. The key differences occur with respect to the required skills and spatial distribution of job offers.

First, we find significant effects of occupational group on the probability of a job being a student job or a flexible job. Relative to the least skilled category of auxiliary 
Table 3 Determinants of student job offers and flexible job offers

\begin{tabular}{|c|c|c|c|c|}
\hline & Student job & Flexible job & Student job & Flexible job \\
\hline & M1 & M2 & M3 & M4 \\
\hline \multicolumn{5}{|l|}{ Occupational category } \\
\hline \multicolumn{5}{|l|}{ Auxiliary worker (reference category) } \\
\hline Qualified labourer & $-0.062^{* * *}$ & $-0.180^{* * *}$ & $-0.062^{* * *}$ & $-0.178^{* * *}$ \\
\hline Administrative worker & $-0.046^{* * *}$ & $-0.215^{* * *}$ & $-0.046^{* * *}$ & $-0.210^{* * *}$ \\
\hline Qualified technical worker & $-0.050^{* * *}$ & $-0.245^{* * *}$ & $-0.051^{* * *}$ & $-0.241^{* * *}$ \\
\hline Qualified non/technical worker & $-0.065^{* * *}$ & $-0.209^{* * *}$ & $-0.065^{* * *}$ & $-0.205^{* * *}$ \\
\hline Lower and middle management & $-0.077^{* * *}$ & $-0.243^{* * *}$ & $-0.077^{* * *}$ & $-0.239^{* * *}$ \\
\hline Top management & $-0.107^{* * *}$ & $-0.319^{* * *}$ & $-0.107^{* * *}$ & $-0.315^{* * *}$ \\
\hline \multicolumn{5}{|l|}{ Sector } \\
\hline \multicolumn{5}{|l|}{ Mining, quarrying and manufacturing (reference category) } \\
\hline Agriculture, forestry and fishing & -0.01 & 0.002 & -0.01 & 0.005 \\
\hline Construction & 0.007 & $0.025^{* *}$ & 0.007 & $0.024^{* *}$ \\
\hline $\begin{array}{l}\text { Wholesale and retail, transportation and storage, } \\
\text { accommodation and food }\end{array}$ & $0.039^{* * *}$ & $0.068^{* * *}$ & $0.040^{* * *}$ & $0.069^{* * *}$ \\
\hline Information and communication & $0.030^{* * *}$ & $0.290^{* * *}$ & $0.031^{* * *}$ & $0.291^{* * *}$ \\
\hline Financial and insurance activities & $0.093^{* * *}$ & $0.181^{* * *}$ & $0.092^{* * *}$ & $0.183^{* * *}$ \\
\hline $\begin{array}{l}\text { Professional, scientific, technical, administrative } \\
\text { and support service activities }\end{array}$ & $0.069^{* * *}$ & $0.129^{* * *}$ & $0.070^{* * *}$ & $0.131^{* * *}$ \\
\hline Public administration, education, social work activities & $0.045^{* * *}$ & $0.161^{* * *}$ & $0.045^{* * *}$ & $0.161^{* * *}$ \\
\hline Other services & $0.083^{* * *}$ & $0.169^{* * *}$ & $0.081^{* * *}$ & $0.167^{* * *}$ \\
\hline \multicolumn{5}{|l|}{ Required education } \\
\hline Minimum education & $-0.057^{* * *}$ & $-0.048^{* * *}$ & $-0.058^{* * *}$ & $-0.048^{* * *}$ \\
\hline Maximum education & $0.024^{* * *}$ & $0.028^{* * *}$ & $0.025^{* * *}$ & $0.028^{* * *}$ \\
\hline Experience & $-0.062^{* * *}$ & $-0.071^{* * *}$ & $-0.062^{* * *}$ & $-0.070^{* * *}$ \\
\hline \multicolumn{5}{|l|}{ Skills } \\
\hline \multicolumn{5}{|l|}{ No skills (reference category) } \\
\hline Administrative skills & -0.008 & $-0.151^{* * *}$ & -0.008 & $-0.151^{* * *}$ \\
\hline Computer skills_-user & $0.034^{* * *}$ & $-0.072^{* * *}$ & $0.034^{* * *}$ & $-0.072^{* * *}$ \\
\hline Computer skills_-programmer & $0.026^{*}$ & $-0.157^{* * *}$ & $0.026^{*}$ & $-0.155^{* * *}$ \\
\hline Computer skills_-administrator & 0.02 & $-0.213^{* * *}$ & 0.019 & $-0.211^{* * *}$ \\
\hline Language skills & -0.001 & $-0.113^{* * *}$ & -0.001 & $-0.112^{* * *}$ \\
\hline Agency offer & $-0.118^{* * *}$ & $-0.294^{* * *}$ & $-0.119^{* * *}$ & $-0.294^{* * *}$ \\
\hline Minimum salary (thousand euro per month) & $-0.028^{* * *}$ & $-0.192^{* * *}$ & $-0.028^{* * *}$ & $-0.193^{* * *}$ \\
\hline \multicolumn{5}{|l|}{ Region } \\
\hline \multicolumn{5}{|l|}{ Bratislavský (reference category) } \\
\hline Banskobystrický & 0.004 & -0.009 & 0.003 & -0.009 \\
\hline Žilinský & 0.001 & $-0.017^{* *}$ & 0.002 & $-0.016^{* *}$ \\
\hline Trenčiansky & $0.010^{* *}$ & $0.020^{* *}$ & $0.010^{* *}$ & $0.018^{* *}$ \\
\hline Trnavský & $0.011^{* * *}$ & $0.017^{* *}$ & $0.011^{* *}$ & $0.017^{* *}$ \\
\hline Nitriansky & 0.004 & $0.017^{* *}$ & 0.003 & $0.017^{* *}$ \\
\hline Prešovský & $0.028^{* * *}$ & -0.001 & $0.030^{* * *}$ & 0.001 \\
\hline Košický & $0.016^{* * *}$ & -0.009 & $0.018^{* * *}$ & -0.008 \\
\hline Slovakia—not specified & $0.018^{*}$ & -0.001 & $0.017^{*}$ & 0.000 \\
\hline Abroad & $0.038^{* * *}$ & $0.019^{* *}$ & $0.037^{* * *}$ & $0.019^{* *}$ \\
\hline
\end{tabular}


Table 3 Determinants of student job offers and flexible job offers (Continued)

\begin{tabular}{|c|c|c|c|c|}
\hline \multicolumn{5}{|l|}{ Year } \\
\hline \multicolumn{5}{|c|}{2009 (reference category) } \\
\hline 2010 & -0.01 & $0.022^{*}$ & & \\
\hline 2011 & $0.016^{*}$ & $0.042^{* * *}$ & & \\
\hline 2012 & $0.019^{* *}$ & $0.053^{* * *}$ & & \\
\hline 2013 & $0.013^{*}$ & $0.019^{*}$ & & \\
\hline 2014 & -0.003 & -0.002 & & \\
\hline \multicolumn{5}{|l|}{ Macroeconomic factors } \\
\hline GDP growth & & & $-0.003^{*}$ & -0.001 \\
\hline Unemployment rate & & & $0.011^{*}$ & $0.018^{*}$ \\
\hline _cons & 0.463 & 3.419 & 0.061 & 0.667 \\
\hline N & 165,313 & 165,313 & 165,313 & 165,313 \\
\hline Pseudo $R^{2}$ & 0.293 & 0.300 & 0.291 & 0.299 \\
\hline
\end{tabular}

${ }^{*} p<0.05 ;{ }^{* *} p<0.01 ;{ }^{* * *} p<0.001$

a Probit with clustered standard errors, clustered at the level of job offer. Marginal effects

${ }^{b}$ Data source for GDP and unemployment: Eurostat

workers, the probability of each is lower if a job vacancy appeared for positions in more skilled occupational categories. This effect, however, is smaller in the case of a dependent variable defined as student job. A job offer which belongs to the top management occupational group is 32 percentage points percentage points (pp) less likely to be based on flexible work contracts but only 11 pp less likely to be targeted directly at students. Similarly, a job offer advertised for a position placed in an administrative worker category is $22 \mathrm{pp}$ less likely to be a flexible offer while only 5 pp less likely to be a student job offer. This can be interpreted as indicating that relative to flexible jobs, student jobs are less strongly concentrated in the least skilled occupational categories.

Second, the sector also distinctly characterizes student offers and flexible offers. Relative to the manufacturing sector, offers that belong to all other sectors, with the exception of agriculture (flexible offers) plus construction (student offers), are more likely to be student offers. The findings generally confirm that both the student labour market and the flexible labour market are concentrated in the service sector, with a stronger probability of this to be the case in flexible job offers than in student job offers. Offers in the information and communication sector were $3 \mathrm{pp}$ more likely to be student than non-student but 29 pp more likely to be flexible than traditional. This constituted the greatest difference between the two labour markets in terms of sectoral concentration.

The 'student-ness' of job offers declines with rising minimum educational requirements attached to a given job offer and rises with maximum educational requirements, and this effect is similar for flexible jobs. If a job offer requires previous experience, it is 6-7 pp less likely to be a student offer or flexible offer. Relative to the requirement of no skills, the probability of a flexible offer declines significantly and substantively if any type of skill is required. On the other hand, we find no effect of administrative and language skills in predicting student job offers, while the requirement of computer skills increases the odds by 3 pp.

Student offers are significantly less likely to be advertised by recruitment agencies implying that companies prefer to target such candidates directly and this is even more the case for flexible job offers that we found to be overwhelmingly low-skilled. With an increasing amount of salary offered, the likelihood of student job offers declines and 
this effect is stronger for flexible work vacancies (19 pp). Student offers are more likely to be advertised for positions outside of Slovakia (4 pp) than in any Slovak region. Within Slovakia, student offers are more likely to be found in the Trenčiansky, Trnavský, Nitriansky and Prešovský regions compared to the Bratislavský and Žilinský regions. This is surprising given the concentration of universities in the Slovak capital. Given that the labour market in the capital city performs well, firms might be more inclined to offer regular job offers in competition for young skilled workers.

Over time, student jobs and flexible jobs have become more widespread. This is more the case for offers based on flexible work contracts than for student offers. It is difficult to distinguish a year effect as this could capture the strategies of firms in post-crisis recovery, as well as legislative changes that have taken place, in particular the amendment to the Labour Code in 2012. However, the unemployment rate has a significant positive effect-a percentage point growth in the unemployment rate increases the probability of student jobs and flexible jobs by 1-2 pp. Improved macroeconomic performance measured by GDP growth seems to negatively impact the occurrence of student offers, but not flexible contract offers.

\section{Conclusions}

With broadened access to tertiary education and growing numbers of students at work, it is crucial to understand the characteristics of the student labour market. This paper looked at patterns of student employment in Slovakia where the number of university students has grown significantly in the context of the relatively inflexible labour market. We studied online job vacancy data and compared 'student jobs' with 'flexible jobs'. While most of the vacancies are non-student and non-flexible, a clear growth trend in student job offers and flexible offers is evident over time. This steep growth can be linked to post-crisis recovery and to legislative changes that took place over the studied period.

Existing academic literature and empirical studies offer only relatively general conclusions about the student labour market and position it in the low-skilled labour market segment, in flexible forms of contractual arrangements and predominantly in the service sector. We indeed confirm that most student vacancies exist in the service sector. We find that there are more offers with flexible work contracts than offers aimed directly at students, and there is some overlap among the two labour markets.

While there are many similarities between the student job market and the flexible job market, they are not identical. First, only a third of the offers with flexible contracts are also categorized as student offers. This supports previous findings that the flexible labour market is broader and covers diverse group workers, such as older workers or mothers. On the other hand, offers aimed at students are often offers with flexible contracts (61\%). This means that nearly $40 \%$ of offers that employers find suitable for students are standard full-time offers.

Second, we find substantive differences in the skill profiles between student-targeted and flexible-contract vacancies. While flexible job offers are systematically less skill demanding than standard job offers, student job offers are characterized by greater emphasis on computer skills and require administrative and language skills on par with nonstudent offers. Moreover, student offers are more diverse in terms of occupational groups and required education, which implies that the student labour market is dispersed across 
the low- and medium-skilled segment of the labour market and is not exclusively concentrated in the least skill-intensive jobs. While this is the case also for the flexible job offers in the Slovak labour market, the degree of concentration in the less skilled segment is higher for flexible offers than for student offers. Younger workers might have an advantage in some specific positions, especially those requiring good language proficiency and vacancies for foreign labour markets that require relocation. Moreover, these findings suggest that student jobs can also complement their education and improve the graduates' position in the labour market. The fact that students' jobs are less strongly linked to educational attainment may signal that they are unrelated to the formal field of study. This aspect would require further analysis which is beyond the scope of this work. Such jobs could still be demanding in soft skills or transversal skills where students or younger workers are likely to possess an advantage.

With respect to the influence of macroeconomic variables on the student labour market, we find that a percentage point growth in the unemployment rate increases the probability of the occurrence a student job relative to a non-student job by $1 \mathrm{pp}$ ). Improved macroeconomic performance measured by GDP growth decreases the occurrence of student offers, but not flexible offers. We also find a significant effect of time variables whereby student job offers have become more widespread since 2012. This could reflect firm strategies in post-crisis recovery as well as legislative changes, such as the Labour Code amendment. These combined findings seem to suggest that student work and flexible work have been used as a means of recovery in the Slovak labour market. Job rich growth, however, is likely to provide opportunities for student work in the primary labour market, rather than on its fringes.

Our study is relevant from a policy perspective as it questions the identification of student work with flexible work. It implies that any regulation of the flexible labour market will only partially address the student labour market. It also provides additional support for arguments against measures limiting labour supply (e.g. early retirement schemes), as skills that student workers and other (typically low-skilled) workers are expected to bring to the labour market are not identical. We believe our findings are generalizable beyond the case of Slovakia and apply more broadly to countries with similar institutional design and a growing tertiary education sector, in particular in Central and Eastern Europe.

\section{Endnotes}

${ }^{1}$ The literature review refers to students and young workers interchangeably, as in most studies, the two are not distinguished.

${ }^{2}$ The data for the year 2014 are available only until June, hence the drop in the number of observations for the year 2014.

${ }^{3} \mathrm{~A}$ partial representativeness analysis based on EU-LFS data was conducted by Štefánik (2012). His key finding was that the data is roughly representative in the high-skilled segment of the employed population as far as occupational groups are concerned, but clerks (ISCO 4) and service workers (ISCO5) are over-represented in both the ads and the CV data. He also found that vacancies in the public sector are under-represented.

${ }^{4}$ The categories are as follows: 1-primary, 2-secondary school student, 3-secondary without leaving certificate, 4-secondary with leaving certificate, 5-university student, 6-higher professional education, 7-BA, 8-MA, and 9- $\mathrm{PhD}$. 
${ }^{5}$ The categories are as follows: full-time employment, part-time employment, work on agreement (dohoda) and self-employment licence (živnost'). Work agreement is 'Dohoda o vykonaní práce' in Slovak. Relative to temporary work contract, it provides fewer employee rights (e.g. no holiday or sick pay); from this perspective, it is less secure.

${ }^{6}$ We adapted the sectoral categorisation used by the portal to NACE Rev.2 classification.

${ }^{7}$ We dealt with the non-exclusivity of categories of four variables-occupational group, sector, region and skills, by leaving the original structure of the dataset and entering the same offer more than once in the analysis when more than one value was ascribed to one (or more) of these variables. Then, we applied clusters for each offer to deal with the non-independence of the observations.

${ }^{8}$ Both macroeconomic variables are measured on a year level.

${ }^{9}$ Year dummies and macroeconomic variables could not be entered in the same model due to collinearity.

\section{Acknowledgements}

We would like to thank Profesia.sk for providing us with the data and in particular to Dalibor Jakuš, Mária Mišečková and Tomáš Janotík. Research assistance from Martin Mýtny in cleaning the dataset is also acknowledged. We would like to thank Felix Hörisch, Peter J. Sloane, Jacqueline O'Reilly, the European Commission's DG for Employment, Social Affairs and Inclusion, two anonymous referees and the editor for the useful comments on earlier versions of this work. All errors remain our own.

Responsible editor: Martin Kahanec

\section{Funding}

The research leading to these results has received funding from the European Union's Seventh Framework Programme for research, technological development and demonstration under grant agreement no. 613256, project STYLE: http://www.style-research.eu/.

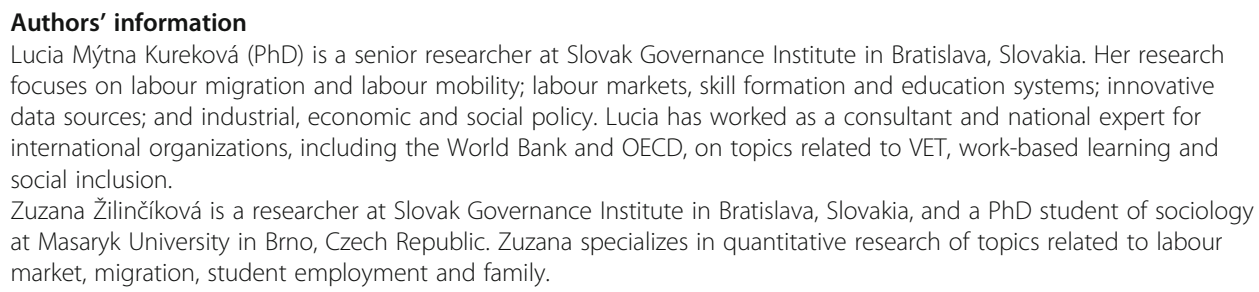

The IZA Journal of European Labor Studies is committed to the IZA Guiding Principles of Research Integrity. The authors declare that they have observed these principles.

\section{Author details}

'Slovak Governance Institute, IZA and CELSI, Štúrova 3, 81102 Bratislava, Slovakia. ${ }^{2}$ Slovak Governance Institute and Masaryk University Brno, Štúrova 3, 81102 Bratislava, Slovakia.

Received: 22 October 2016 Accepted: 22 November 2016

Published online: 08 December 2016

\section{References}

Askitas N, Zimmermann K (2015) The Internet as a data source for advancement in social sciences. Int J Manpow 36:2-12. doi:10.1108/JJM-02-2015-0029

Autor DH, Levy F, Murnane RJ (2003) The skill content of recent technological change: an empirical exploration. Q J Econ 118:1279-1333. doi:10.1162/003355303322552801

Babcock P, Marks M (2011) The falling time cost of college: evidence from half a century of time use data. Rev Econ Stat 93:468-478. doi:10.1162/REST_a_00093

Baffoe-Bonnie J, Golden L (2007) Work-study: time use tradeoffs, student work hours and implications for youth employment policy. For the IATUR - XXVIIII Annual Conference, Washington, DC, http://papers.ssrn.com/sol3/ papers.cfm?abstract_id=1078688. Accessed 20 March 2014

Beblavý M, Lehouelleur S, Maselli I (2013) Useless degrees or useless statistics?: a comparison of the net present value of higher education by field of study in five European countries. NEUJOBS Working Paper 4.4.2A, CEPS, Brussels, https://papers.ssrn.com/sol3/papers.cfm?abstract_id=2402716. Accessed 20 Mar 2014

Beblavý M, Kureková LM, Haita C (2016) The surprisingly exclusive nature of medium- and low-skilled jobs: evidence from a Slovak job portal. Pers Rev 45:255-273. doi:10.1108/PR-12-2014-0276 
Beerkens M, Mägi E, Lill L (2010) University studies as a side job: causes and consequences of massive student employment in Estonia. High Educ 61:679-692. doi:10.1007/s10734-010-9356-0

Broadbridge A, Swanson V (2005) Earning and learning: how term-time employment impacts on students adjustment to university life. J Educ Work 18:235-249. doi:10.1080/13639080500086008

Broadbridge A, Swanson V (2006) Managing two roles. Community Work Fam 9:159-179. doi:10.1080/13668800600586878

Brunello G, Schlotter M (2011) Non-cognitive skills and personality traits: labour market relevance and their development in education \& training systems. IZA discussion paper no. 5743. Institute for the Study of Labor (IZA), Bonn

Canny A (2002) Flexible labour? The growth of student employment in the UK. J Educ Work 15:277-301. doi:10.1080/ $1363908022000012058-2$

Caroleo FE, Pastore F (2007) The youth experience gap: explaining differences across EU countries. Quad Dipartimento Econ Finanza E Stat 41:2007

Choudhry MT, Marelli E, Signorelli M (2012) Youth unemployment rate and impact of financial crises. Int J Manpow 33:76-95. doi:10.1108/01437721211212538

Curtis S, Lucas R (2001) A coincidence of needs?: employers and full-time students. Empl Relat 23:38-54. doi:10.1108/ 01425450110366264

CVTI SR (2016) Časové rady: vysoké školy (Time series: universities). Centrum vedecko-technickych informacii SR., http:// www.cvtisr.sk/cvti-sr-vedecka-kniznica/informacie-a-prognozy-skolstva/statistiky/casove-rady.html?page_id=9724. Accessed 14 July 2016

Del Boca D (2002) The effect of child care and part time opportunities on participation and fertility decisions in Italy. J Popul Econ 15:549-573. doi:10.1007/s001480100089

Edelman B (2012) Using Internet data for economic research. J Econ Perspect 26:189-206. doi:10.2307/41495310

Eichhorst W, Boeri T, Braga M et al (2013) Combining the entry of young people in the labour market with the retention of older workers, IZA Research Report no. 53. Institute for the Study of Labor (IZA), Bonn

Fabo B, Beblavý M (2015) Students in work and their impact on the labour market, Working Document no. 410. CEPS, Brussels

Ford J, Bosworth D, Wilson R (1995) Part-time work and full-time higher education. Stud High Educ 20:187-202. doi:10.1080/03075079512331381693

Guile D, Griffiths T (2010) Learning through work experience. J Educ Work 14:113-131. doi:10.1080/13639080020028738

Häkkinen I (2006) Working while enrolled in a university: does it pay? Labour Econ 13:167-189. doi:10.1016/j.labeco. 2004.10.003

Hall R (2010) The work-study relationship: experiences of full-time university students undertaking part-time employment. J Educ Work 23:439-449. doi:10.1080/13639080.2010.515969

Hazans M (2011) Informal workers across Europe: evidence from 30 countries, IZA Discussion Paper no. 5871. Institute for the Study of Labor (IZA), Bonn, http://www.econstor.eu/handle/10419/51842. Accessed 25 May 2014

Hirsch BT (2005) Why do part-time workers earn less? The role of worker and job skills. Ind Labor Relat Rev 58:525-551. doi:10.1177/001979390505800401

Kalleberg AL (2000) Nonstandard employment relations: part-time, temporary and contract work. Annu Rev Socio 1:341-365. doi:10.1146/annurev.soc.26.1.341

Kelly E, McGuinness S (2015) Impact of the Great Recession on unemployed and NEET individuals' labour market transitions in Ireland. Econ Syst 39:59-71

Kureková LM, Beblavý M, Haita C, Thum A-E (2015) Employers' skill preferences across Europe: between cognitive and non-cognitive skills. J Educ Work 27:1-26. doi:10.1080/13639080.2015.1024641

Little B, Arthur L (2010) Less time to study, less well prepared for work, yet satisfied with higher education: a UK perspective on links between higher education and the labour market. J Educ Work 23:275-296. doi:10.1080/ 13639080.2010 .484415

Manning A (2004) We can work it out: the impact of technological change on the demand for low-skill workers. Scott Polit Econ 51:581-608. doi:10.1111/j.0036-9292.2004.00322.x

Maselli I (2012) The evolving supply and demand of skills in the labour market. Intereconomics 47:22-30

Maxwell NL (2006) The working life: the labor market for workers in low-skilled jobs. WE Upjohn Institute, Kalamazoo

Monitor AIM (2014) Výskum sociodemografie návštevníkov internetu v Slovenskej Republike. IAB Slovakia, Mediaresearch \& Gemius., http://www.iabslovakia.sk/wp-content/uploads/2014/10/2015_04_TOTAL.pdf. Accessed 14 July 2016

Moreau M-P, Leathwood C (2006) Balancing paid work and studies: working (-class) students in higher education. Stud High Educ 31:23-42. doi:10.1080/03075070500340135

O'Higgins N (2012) This time it's different? Youth labour markets during "The Great Recession". Comp Econ Stud 54:395-412. doi:10.1057/ces.2012.15

Pfeffer J, Baron N (1988) Taking the workers back out. Res Organ Behav 10:257-303

Pollmann-Schult M (2005) Crowding-out of unskilled workers in the business cycle: evidence from West Germany. Eur Sociol Rev 21:467-480. doi:10.1093/esr/jci033

Purcell K, Elias P (2003) Measuring change in the graduate labor market, Research Paper no. 1. IER, Warwick

Purcell K, Elias P, Wilton N (2004) Higher education, skills and employment: careers and jobs in the graduate labour market. IER, Warwick

Quintini G, Manfredi T (2009) Going separate ways? School-to-work transitions in the United States and Europe. OECD, Paris

Quintini G, Martin S (2006) Starting well or losing their way? OECD, Paris

Quintini G, Martin S (2014) Same but different: school-to-work transitions in emerging and advanced economies. OECD, Paris

Ryan P (2001) The school-to-work transition: a cross-national perspective. J Econ Lit 39:34-92. doi:10.1257/jel.39.1.34

Scarpetta S, Sonnet A, Manfredi T (2010) Rising youth unemployment during the crisis. How to prevent negative long term consequences on a generation? OECD Social, Employment and Migration Working Papers 106. OECD, Paris, http://www.oecd-ilibrary.org/social-issues-migration-health/rising-youth-unemployment-during-the-crisis_ 5kmh79zb2mmv-en. Accessed 21 Mar 2015

Štefánik M (2012) Internet job search data as a possible source of information on skills demand (with results for Slovak university graduates). In: Building on skills forecasts - Comparing methods and applications (ed) CEDEFOP.

Publications Office of the European Union, Luxembourg 